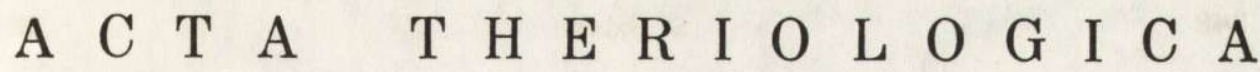

VOL. $19,23: 347-354$.

BIAEOWIEŻA

September, 1974

\author{
Stanisław S Z T E Y N
}

\section{Nucleus Olivaris in the Beaver}

[With 1 Table \& Plates V-VI]

\begin{abstract}
The study was made on the brains of three beavers varying in age from 6 to 18 months. The material was fixed in neutralized formalin, dehydrated in ethyl alcohol, embedded in paraffin and sectioned to $15 \mu$. Every second section was taken for examination. Sections were stained alternately by the Nissl and Kluver-Barrera methods. The oliva in the beaver, like that in other mammals, is formed of three parts: nucleus olivaris principalis, nucleus olivaris accessorius medialis and nucleus olivaris accessorius dorsalis. A characteristic feature of nucleus olivaris in the beaver is the relatively very strongly formed nucleus olivaris principalis, which extends over an area equal to $92 \%$ of the lenght of the whole complex of this nucleus and the weak formation of nucleus olivaris accessorius dorsalis. The lenght of this part is only equal to $45 \%$ of the lenght of the whole nucleus olivaris.
\end{abstract}

\section{INTRODUCTION}

Despite the fairly considerable number of studies which have been made on nucleus olivaris in mammals, many of the questions connected with the function of this important co-ordinating centre have not been fully investigated up to the present. It would seem that continued progress in such studies depends not only on experimental work (which on account of the difficulty of acces to this centre is very complicated), but also morphological studies on the largest possible number of different species of mammals. Comparative anatomical conclusions reached on the basis of such studies could prove very useful in elucidating the function of nucleus olivaris, which has remained an open question up to the present.

The morphology of nucleus olivaris has examined only in certain mammals. For instance, among ungulates Lewandowski (1952) described this nerve centre in pigs, Szteyn (1967) in sheep, Kolda (1928) in a cow, Milart (1965) in a horse, Szteyn \& Welento $(1967 \mathrm{a}, \mathrm{b})$ in a goat and roe-deer, and Wele $\mathrm{n}$ to \& S z te yn (1967) in wild boar, Brodal (1940), Yoda $(1940,1941)$ and Taber (1961) 
made studies of nucleus olivaris in carnivores, $\mathrm{Sch}$ ober (1959/60) in Myotis myotis (Borkh a us en, 1967), and Meessen \& Olszewski (1949) in a rabbit. Nucleus olivaris has been examined only in the guinea pig ( $\mathrm{H}$ of $f \mathrm{mann}, 1957)$ and nutria (S z teyn, 1965), from among the numerous rodents. The purpose of the present study is to obtain information on the morphology of nucleus olivaris in the beaver, a rodent with a very characteristic way of life.

\section{MATERIAL AND METHODS}

Studies were made on the encephalon of 3 beavers (Castor fiber Lin$n$ a e us, 1758) varying in age from 6 to 18 months. The study material was fixed in neutralized formalin, dehydrated with ethyl alcohol, then embedded in paraffin and cross-sectioned to $15 \mu$. Every second section was taken for examination, staining alternately by the Nissl and Kluver-Barrera methods.

\section{RESULTS}

Nucleus olivaris in the beaver, as in other mammals, consists of three groups of cells: nucleus olivaris accessorius medialis, nucleus olivaris accessorius dorsalis and nucleus olivaris principalis, the whole being situated in the beaver in the ventro-medial part of medulla oblongata. Two third of the anterior parts of this centre are situated in front of, and $1 / 3$ behind, calamus scriptorius. Nucleus olivaris accessorius medialis (Om, $\mathrm{O} m \mathrm{~m}, \mathrm{O} m v$ - Fig. 1-5) forms the ventro-central part of the whole group of nucleus olivaris. From the posterior side $\mathrm{Om}$ extends further than the other parts of nucleus olivaris and independently forms about $1 / 6$ of the posterior part of this centre. In front it disappears earlier than nucleus olivaris principalis and the dorsal part of the whole complex - at the level of the posterior limit of $1 / 9$ of the anterior part of nucleus olivaris. In the beaver the average length of $\mathrm{Om}$ is about $90 \%$ of the length of the whole complex.

$\mathrm{O} m$ is an elongated, flat band cells in which two laminae, horizontal and vertical, can be distinguished. The two laminae are situated at an obtuse angle in relation to each other. The vertical lamina runs parallel to the central plane and sature of medulla oblongata, and the horizontal lamina is situated diagonally from the dorso-central side towards the ventro-lateral side. The ventral end of the vertical lamina is connected with the central margin of the horizontal lamina, which is far more strongly formed than the vertical lamina, which occurs only in the middle part of $\mathrm{Om}$. The anterior and posterior part of this part of the oliva are 
formed only by the horizontal lamina. The vertical lamina is connected in its central part for a short space with the lower arm of nucleus olivaris principalis.

Nucleus olivaris accessorius dorsalis (Od - Fig. 3-5) occupies a dorso-lateral position in the nucleus olivaris complex. Od is the shortest and most weakly formed part of the oliva. From the rear it begins at a slight distance caudad from midway along the length of nucleus olivaris, and in the front disappears at the level of the posterior limit of $1 / 10$ of the anterior part of the whole oliva complex. The length of $O d$ is on an average equal to about $45 \%$ of the length of nucleus olivaris.

$O d$ takes the form of a flat, elongated lamina of grey matter situated diagonally in relation to the dorso-central side towards the centro-lateral side. $O d$ is situated dorsal and laterally from nucleus olivarius principalis and lies parallel to its upper arm. In the central part of Od its dorsomedial margin bends in a ventromedial direction and connects for a short space with the upper arm of nucleus olivaris principalis. The anterior part of $O d$ is an oval group of cells lying above the arm, $O p$.

Nucleus olivaris principalis (Op, Ops, Opv - Fig. 2-6) is the longest and best formed part of the oliva in the beaver. $O p$ lies between $O m$ and $O d$. In front $O p$ extends further than the other parts of the complex and independently forms the capitad part of nucleus olivaris. The posterior pole of $O p$ appears above $O m$ at a slight distance caudad from the anterior limit of $1 / 10$ of the posterior part of nucleus olivaris. The part of the oliva complex described extends over $92 \%$ of its total length.

In cross-sections $O p$ has the form of an elongated, narrow letter $U$, situated diagonally from the dorsocentral side towards the ventro-lateral side. It is possible to distinguish in $O p$ the upper arm situated bellow $O d$ and running parallel to it, and the lower arm situated above the horizontal lamina $\mathrm{Om}$. The ventro-lateral margin of both arms of $\mathrm{Op}$ are connected with each other by an arched band of grey matter, while the opposite ends are separated from each other and form the open end of a letter $\mathrm{U}$. There is a narrow, celless sinus between the two arms of $O p$. The upper arm of $O p$ is thicker and far better formed than the lower arm. The upper arm $O p$ connects for a short distance, at the level of the central part of Od, with its dorso-central end from Od.

The cytoarchitectonics of all parts of nucleus olivaris is similar. The whole complex of the nucleus is formed from rounded and oval cells and less numerous multipolar cells measuring from 20 to $30 \mu$. Single fusiform cells, the dimensions of which along the long axis are as much as $35 \mu$, also occur sporadically in all parts of oliva. The cells of nucleus olivaris have spherical nuclei, with the nucleolus situated centrally and a large amount of mediumsized granules of tigroid substance. 


\section{DISCUSSION}

The basic plan of the structure of nucleus olivaris in the beaver is similar to this nerve centre in other mammals, but the formation of the various parts exhibits many features characteristic of the species.

$O p$ is very strongly formed in the beaver in comparison with not only ungulates, in which it is weakly developed, but also in comparison with such species as the cat, nutria or seal (Table 1). $O p$ in the beaver is relatively longer even than in certain Primates, despite the fact that these are characterized by its very strong formation. It must also be emphasised that $O p$ in the beaver does not exhibit the folding which is encountered in Primates.

Experimental studies (Broda l, 1940; B r o uver \& C oe ne n, 1919; Yoshimura, 1910) have shown that $O p$, a phylogenetically younger formation than the two para-olivae, has numerous fibres connecting with neocerebellum, but not cannecting with paleocerebellum. K a p pers (1960) and the majority of other authors consider that $O p$ is connected with the movement of the thoracic limbs, in particular with the mobility of the free part of these limbs. This explains the very strong formation of $O p$ in mammals with thoracic limbs of the prehensile type, which perform complicated and precise movements. The very strong formation of $O p$ in the beaver would appear to be connected with the considerable capacity for movement of the free part of its thoracic limb.

A second characteristic feature of the oliva in the beaver is the very weakly formed $O d$, which occurs only over an area equal to $45 \%$ of the length of nucleus olivaris and is the most weakly formed of all those found in mammals examined from this aspect (Table 1). In the nutria Od is most similar in shape and size to this part of nucleus olivaris in the beaver ( $\mathrm{Sz}$ te y $\mathrm{n}, 1965)$. It is difficult at present to ascertain whether the weak formation of $\mathrm{Od}$ is a characteristic feature of rodents in general, or a character specific to the beaver and nutria, and discussion of this questions is even more difficult, in view of the fact that we know least about the function of $O d$. It is in fact only known that $O d$, like $O m$, is closely connected with the paleocerebellum. Only Brunner (1917) puts forward the assumption that this centre co-ordinates the function of the pelvic limbs, but it is difficult to agree with this hypothesis, vearing in mind for instance the strong development of $O d$ in the bat (S ch ober, 1959/60), the pelvic limbs of which cannot be considered very mobile and operative. Similar relations were found in the case of Od in wild boar (W e l e n to \& S z t e y n, 1967). When contrasted with the fact of far more weak formation of $O d$ in, for instance, the cat, nutria and beaver (Table 1), it is difficult to agree with Brunner's 
assumpt ons (1917). It would seem that many further studies on mammals leading a different way of life and exhibiting different ways of locomotion are neces sary to explain the function of the dorsal para-oliva.

The re atively strong formation of $\mathrm{Om}$ in the beaver does not exhibit particularly characteristic features of this species. This forms support for the views, neld up to the present on the function of this part of the oliva. The majority of authors consider that $\mathrm{Om}$ is a centre co-ordinating movements connected with maintenance of body balance and controlling the movements of the spine.

The location of nucleus olivaris in the sagittal plane in the beaver a)pears interesting, that is, the protrusion of $2 / 3$ of the complex in front of calamus criptorius. This does not confirm V e r m e u le n's theory (1924) that nucle s oliveris has shifted in an anterior direction in domestic

Table 1

Proportions of different parts of nucleus olivalis in percentages of lenght of the whole oliva complex in different species of mammals.

$\mathrm{Od}$ - oliva dorsalis, $\mathrm{Om}$ - oliva medialis, $\mathrm{Op}$ - oliva principalis.

\begin{tabular}{|c|c|c|c|c|}
\hline Species & Od & $\mathrm{Om}$ & $O p$ & References \\
\hline Bos taurus & 69 & 81 & 50 & Kolda (1928) \\
\hline Equs caballus & 81 & 80 & 51 & Lewandowski (1952) \\
\hline Sus domestica & 75 & 85 & 50 & Milart (1965) \\
\hline Ovis domestica & 72 & 86 & 54 & Szteyn (1967) \\
\hline Capra domestica & $7 \overline{1}$ & 81 & 55 & Szteyn \& Welento (1966) \\
\hline Sus scrofa & 91 & 94 & 46 & Welento \& Szteyn (1967) \\
\hline Capreolus capreolus & 83 & 94 & 57 & Szteyn \& Welento (1967) \\
\hline Felis domesticus & 75 & about 100 & 60 & Taber (1961) \\
\hline Phoca vitulina & - & about 100 & 65 & Kooy (1917) \\
\hline Cebus fatuellus & - & - & 71 & Kooy (1917) \\
\hline Myotis myotis & 90 & about 100 & 33 & Schober $(1959 / 60)$ \\
\hline Myocastor coypus & 63 & 84 & 62 & Szteyn (1964) \\
\hline Oryctolagus cuniculus & - & about 100 & - & Hoffmann (1957) \\
\hline Castor fiber & 45 & 90 & 92 & This paper \\
\hline
\end{tabular}

animals. Taking calamus scriptorius as a point of reference, the oliva in the beaver lies as far forward as nucleus olivaris in sheep (Szte y n, 1967), and far further forwards than the oliva in the goat ( $\mathrm{S} z$ t e y $\mathrm{n}$ \& W e l e n to, 1967) or pig (L e w a nd ow s ki, 1952). The beaver is inferior in this respect only to the horse ( $\mathrm{Mil}$ a r t 1965), in which as much as $3 / 4$ of the complex of nucleus olivaris is situated in front of calamus scriptorius. V e rm e ule n's theory (1924) has in fact been overthrown earlier, as Welento \& Szteyn (1967) found that in the wild boar its arrangement in the sagittal plane is identical with that in domestic pigs. The cell structure in the oliva in the beaver is similar to the 
cytoarchitectonics of this nucleus in other mammals, and does not exhibit separate species characters.

\section{REFERENCES}

1. Brodal A., 1940: Experimentelle Untersuchungen über die Olivocerebellare Lokalisation. Ztschr. Ges. Neurol. Psychiat., 169, 1: 1-153.

2. Brouver E. \& Coenen L., 1919: Uber die Oliva inferior. J. Psych. Neurol., 25: $52-71$.

3. Brunner H., Zur Kenntnis der unteren Olive bei den Säugetieren. Arb. Neurol. Inst. Wiener Univ., 12, 1: 113-199.

4. Hof $\mathrm{fmann}$ G., 1957: Atlas von Hirstamm des Meerschweinchens. S. Hirzel Verlag, Leipzig.

5. Kappars A., 1960: The comparative anatomy of the nervous system of vertebrates including man. Hafner Publ. Co., 1: 668-689, New York.

6. Kolda J., 1928: L'olive inférieure du boeuf. Comptes Rendeus de l'Association des Anatomistes: 1-8, Praque.

7. Ko о y F., 1917: The inferior olive in vertebrates. Folia Neurobiol., 10: 205-369.

8. Lewandowski M., 1952: Oliwa dolna (nucleus olivaris inferior) świni. Annls Univ. M. Curie-Skłodowska, DD 6: 294-307.

9. Meessen H. \& Olszewski J., 1949: Cytoarchitektonischer Atlas des Rautenhirns des Kaninchens. S. Karger Verlag: 14-23 und 45, Basel.

10. Milart Z., 1965: Die Olive des Pferdes. Wiener tierärztl. Monatschr., 52, 4: $223-230$.

11. Schober W., 1959/60: Zur Cytoarchitektonik und Cytologie der Medulla oblongata der Mausohr-Fledermaus Myotis myotis (Borkhausen). Wissen, Ztschr. Karl Marx Univ., 9, 5: 745-771.

12. Szteyn S., 1965: Oliwa tylna (nucleus olivaris caudalis) nutrii (Myocastor coypus Molina). Annals Univ. M. Curie-Skłodowska, C 19: 177-188.

13. S z t e y n S., 1967: Oliwa (nucleus olivaris) owcy (Ovis aries). Polskie Arch. wet., 10: $405-416$.

14. Szteyn S. \& W ele n to J., 1967a: Oliwa (nucleus olivaris) kozy (Capra dom.). Annls Univ. M. Curie-Skłodowska, DD 21: 207-217.

:5. Szteyn S. \& W el ento J., 1967b: Oliwa (nucleus olivaris) sarny. Polskie Arch. wet., 10: $671-684$.

16. Taber E., 1961: The cytoarchitecture and cytologie of the brain stem of the cat. J. comp. Neurol., 116, 1: 27-56.

17. Vermeulen H. A., 1924: De involoed van het huisdieworden op den bouw der hersenen. Nederl. Zijdschr. Geneesk., 68, 2: 1931-1946.

18. Welento J. \& Szteyn S., 1967: Die Olive (nucleus olivaris) des Wildschweines. Acta theriol., 12, 8: 93-103.

19. Yoda S. 1940: Uber die Kerne der Medulla oblongata der Katze. Ztschr. mikroskop.-anat. Forsch., 48: 529-582.

20. Yod a S., 1941: Beitrag zu den Olivenkernen des Hundes. Ztschr. mikroskop.-anat. Forsch., 49: 516-524.

21. Yos chimura K., 1910: Experimentelle und vergleichende anatomische Untersuchungen über die untere Olive der Vögel. Arb. Neurol. Inst. Wiener Univ., 18, 1: 46-79. 
Stanisław SZTEYN

\section{OLIWA BOBRA}

Streszczenie

Praca została wykonana na mózgowiach trzech bobrów w wieku od 6 do 18 miesięcy. Materiał utrwalono w zneutralizowanej formalinie, odwadniano w alkoholu etylowym, zatapiano w parafinie i cięto na skrawki poprzeczne grubości $15 \mu$. Do badań brano co drugi skrawek. Skrawki barwiono na przemian metodami Nissla i Klüঈera-Barrery.

Oliwa bobra, podobnie jak oliwa innych ssaków utworzona jest z trzech części: nucleus olivaris principalis, nucleus olivaris accessorius medialis i nucleus olivaris accessorius dorsalis. Cechą charakterystyczną nucleus olivaris bobra jest stosunkowo bardzo silne wykształcenie oliwy głównej, która rozciąga się na przestrzeni równej $92 \%$ długości całego kompleksu tego jądra oraz słabe wykształcenie nucleus olivaris accessorius dorsalis. Długość tej części wynosi tylko 45\% długości całego jądra oliwy.

Accepted, March 10, 1974.

Teachers Training College, Departament of Biology,

Żołnierska 14,

10-561 Olsztyn, Poland. 


\section{EXPLANATIONS TO PLATES V-VI}

Figs. 1-6. Cross-sections of medulla oblongata in the beaver. Fig. 1. Near posterior pole of nucleus olivaris.

Fig. 2. Near the posterior pole of nucleus olivaris principalis.

Fig. 3. Midway along length of nucleus olivaris.

Fig. 4. Midway along length of nucleus olivaris accessorius dorsalis.

Fig. 5. Near anterior pole of nucleus olivaris accessorius dorsalis.

Fig. 6. Near anterior pole of nucleus olivaris.

Explanation to symbols:

$\mathrm{O} m$ - oliva medialis,

$\mathrm{O} m \mathrm{~m}$ - horizontal lamina of oliva medialis,

Omv - vertical lamina of oliva medialis,

Od - oliva dorsalis,

Op - oliva principalis,

Ops - upper arm of nucleus olivaris principalis,

Opv - lower arm of nucleus olivaris principalis,

$\mathrm{S}-$ sinus of nucleus olivaris principalis,

1 - lateral side,

$\mathrm{m}-$ medial side. 
ACTA THERIOLOGICA, Vol. XIX, 23.

Plate V.
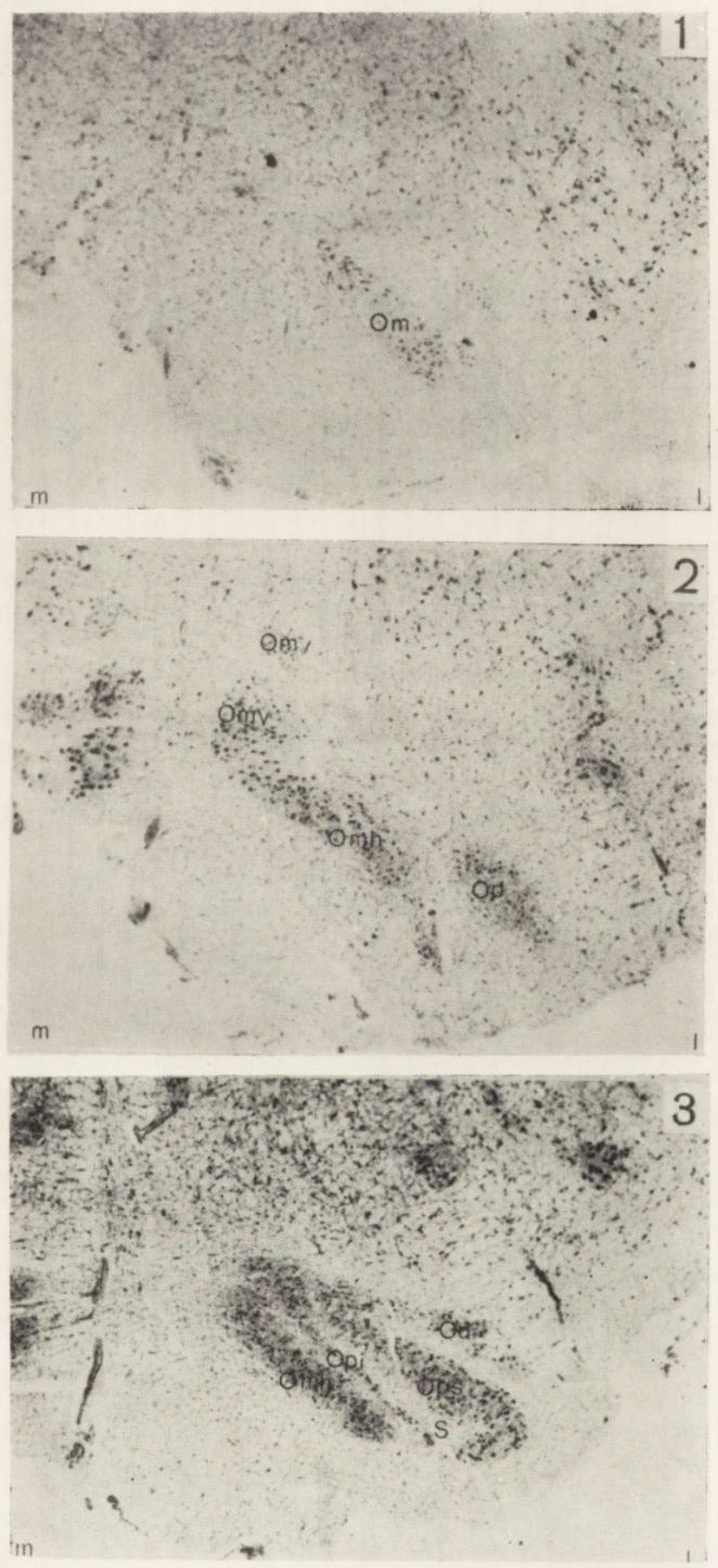

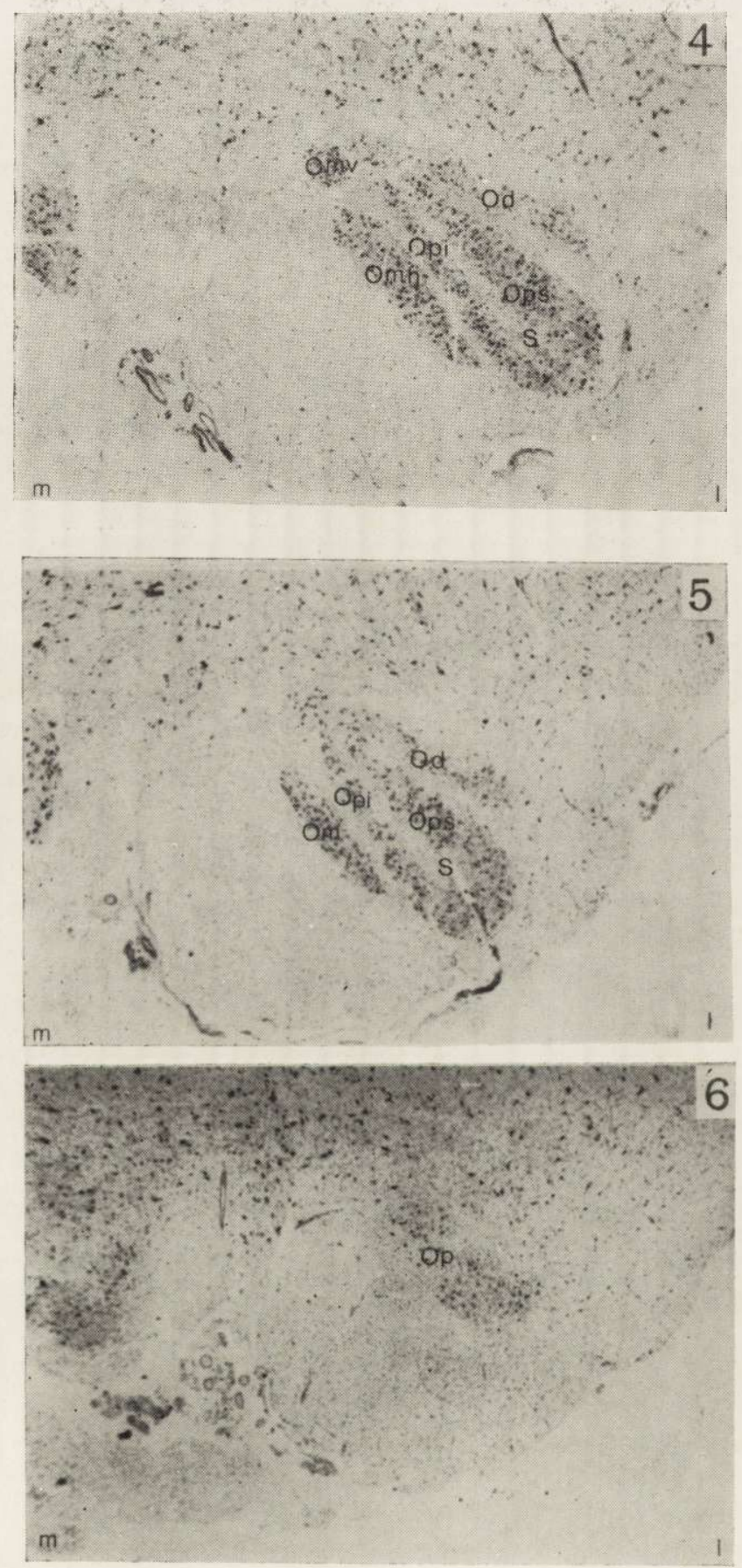